\title{
PENGEMBANGAN ALAT PERAGA BAK SIMULASI RIAK GELOMBANG PADA MATERI GELOMBANG UNTUK PESERTA DIDIK SMA/MA
}

\author{
Riska Putri $^{1}$, Rahma Diani ${ }^{1 *}$, Yuberti $^{1}$ \\ ${ }^{1}$ Pendidikan Fisika Universitas Islam Negeri Raden Intan Lampung, Indonesia \\ *corresponding author : ramhadiani@ radenintan.ac.id
}

\begin{abstract}
Article History:
Received: Januari 21, 2020

Revised : Februari 12, 2020

Accepted: April 30, 2020

Published: Juni 30, 2020
\end{abstract}

Keywords: Alat Peraga, $R \& D$, sifat-sifat gelombang

\begin{abstract}
This research aims to develop physics learning media in the form of ripple tank on wave subject. One of the problems in education is the lack of facilities and infrastructure, so teachers are required to be creative in improving learning quality in the classroom, such as making props as one of the learning media. One of the interesting learning media that can overcome students' boredom in learning is through propsmaking based learning. The method used in this study is research and development. The type of research used is the $4 D$ model. The data in this study were collected in the form of a questionnaire given to content experts, media experts, teachers and 10th-grade students. The type of data generated is qualitative and quantitative data to determine the accuracy of the products, so that, it can produce physics learning media in the form of props that is valid for use based on the assessment of the content expert validator and the media expert validator with very accurate categories, and based on the assessment from teachers and students got scores with very interesting categories. This shows that the product developed can be used in learning to facilitate students in understanding wave subject.
\end{abstract}

\begin{abstract}
Abstrak: Penelitian ini bertujuan untuk mengembangkan media pembelajaran fisika berupa alat peraga bak riak gelombang pada materi gelombang. Salah satu permasalahan pendidikan adalah minimnya sarana dan prasaranan, sehingga guru dituntut kreatif dalam meningkatkan kualitas pembelajaran dikelas, seperti membuat alat peraga sebagai salah satu media pembelajaran. Salah satu media pembelajaran yang menarik dan mengatasi kebosanan peserta didik dalam kegiatan pembelajaran yaitu pembelajaran berbasis membuat alat peraga. Metode yang digunakan adalah penelitian dan pengembangan Jenis penelitiaan yang digunakan yaitu model 4D. Pengumpulan data yang digunakan dalam penelitian ini berupa angket yang diberikan kepada ahli materi, ahli media, guru kelas dan peserta didik kelas X. Jenis data yang dihasilkan adalah data kualitatif dan data kuantitatif untuk menentukan keakuratan produk penelitian dan pengembangan menghasilkan media pembelajaran fisika berupa alat peraga yang valid untuk digunakan berdasarkan penilaian dari validator ahli materi dan validator ahli media memperoleh kategori sangat akurat, penilaian pendidik dan peserta didik memperoleh kategori sangat menarik. Hal ini menunjukkan bahwa produk yang dikembangkan dapat digunakan dalam pembelajaran guna mempermudah memahami materi gelombang.
\end{abstract}

\section{PENDAHULUAN}

Era modern sekarang, Ilmu Pengetahuan dan Teknologi (IPTEK) sudah berkembang amat pesat khususnya di Indonesia (Huriawati, Purwandari, \&
Permatasari, 2015; Ulmi, Murtiani, \& Hidayati, 2013). Sehingga dalam mengimbangi kemajuan IPTEK, peningkatan kualitas pada pembelajaran sains yang menjadi tantangan dunia 
pendidikan (Subekti \& et al., 2018). Pendidikan baik yang dapat memberi kontribusi kepada majunya suatu bangsa (Prihatiningtyas, Prastowo, \& Jatmiko, 2012; racy religia, 2017; Suprihatiningsih \& Wiyarno, 2015). Mewujudkan pendidikan yang baik membutuhkan beberaa upaya dalam pembelajaran. Pembelajaran seperangkat tindakan yang dirancang untuk mendukung proses belajar peserta didik, salah satu upaya proses belajar (Muslem, 2017). Proses belajar dibutuhkan perantara yaitu media pembelajaran sebagai variasi dalam proses belajar mengajar, media pembelajaran menjadi unsur penting dalam kegiatan belajar mengajar (Saregar, 2016).

Media pembelajaran yang baik dapat menyenangkan dan mudah dipelajari oleh peserta didik selama proses belajar berlangsung (Kasih, 2017). Media dalam proses pembelajaran dapat berupa software dan hardware. Software dan hardware bagian kecil dari teknologi pembelajaran yang harus diciptakan atau dikembangkan, digunakan dan dikelola untuk kebutuhan pembelajaran dalam mencapai efektivitas dan efesiensi proses pembelajaran (Lubis \& Ikhsan, 2015).

Selain itu, pemakaian media pembelajaran dalam proses belajar juga dapat membangkitkan keinginan dan minat yang baru bagi peserta didik, membangkitkan motivasi belajar, bahkan membawa pengaruh psikologis terhadap peserta didik (Rahman, Hidayat, \& Yanuttama, 2017). Salah satu materi yang perlu di tambahkan media adalah materi yang bersifat abstrak namun terjadi dalam kehidupan sehari-hari khususnya pada materi fisika (Sohibun \& Ade, 2017).

Mata pelajaran fisika diberikan kepada semua peserta didik agar mempunyai kemampuan berpikir logis, analitis, sistematis, kritis, kreatif serta kemampuan bekerjasama. Oleh karenanya dalam pelajaran fisika dibutuhkan media untuk membantu proses belajar salah satunya media tersebut adalah alat peraga.

Alat peraga dapat berupa benda yang berupa manusia, objek atau benda mati yang dipakai sebagai alat bantu dalam pembelajaran. Tujuan alat peraga agar pembelajaran lebih menarik sehingga motivasi belajar peserta didik muncul, materi lebih mudah dipahami dan peserta didik akan lebih aktif dalam proses belajar (Nomleni \& Manu, 2018).

Berdasarkan hasil pra penelitian di tiga sekolah yaitu SMA Negeri 1 Kedondong, SMA Negeri 1 Way Limah, dan Madrasah Aliyah Negeri Pesawaran Lampung, mendapatkan hasil yaitu Keterbatasan alat praktikum serta media pembelajaran yang digunakan masih belum efektif dan efisien. Kebutuhan guru dalam mengembangkan materi pembelajaran tidak semuanya terpenuhi dalam laboratorium. Belum terdapat media pembelajaran berupa alat peraga pada materi gelombang dan sifat-sifat fisisnya. Materi gelombang pada peserta didik kelas XI kelas semester genap dianggap peserta didik masih terlalu abstrak dan butuh visualisasi. Kesimpulan hasil pra penelitian yaitu hasil dalam proses pembelajaran fisika yang berlangsung selama ini sudah berjalan baik, walaupun masih banyak sarana prasarana yang tidak terpenuhi khususnya alat peraga pada laboratorium.

Salah satu cara untuk memenuhi sarana berupa alat peraga dengan membuat alat peraga sederhana. Pada materi gelombang sering kali peserta didik melihat di lingkungan sekitar, namun tidak disadari bahwa hal tersebut salah satu penerapan fisika dalam kehidupan sehari-hari. Beberapa peneliti sebelumnya telah mengembangkan alat peraga fisika pada materi gerak melingkar (Desy, Desnita, \& Raihanati, 2015), materi resultan gaya (Irsyadsyah \& Prabowo, 2015), materi usaha dan energi (Maharani, Wati, \& Hartini, 2017), materi vector (Muzaky \& Handhika, 2015), 
materi fluida statis (Prihatiningtyas \& Putra, 2018), materi koefisien restitusi (Saepuzaman \& Yustiandi, 2017) dan alat praktikum gelombang melde (Widayanti \& Yuberti, 2018). Fokus penelitian ini mengembangkan alat peraga gelombang berupa bak simulasi riak gelombang.

\section{METODE PENELITIAN}

Penelitian ini menggunakan metode penelitian dan pengembangan (Researchand Development) dimodifikasi dari Thiagarajan yang terdiri dari empat tahap, yaitu: 1) pendefinisian (define), 2) perancangan (design), 3) pengembangan (develop), dan 4) penyebaran (desseminate)

Tahap penyebaran dalam penelitian ini belum dilakukan baru sampai pada tahap pengembangan dengan melakukan uji coba produk. Gambar 1 berikut uraian metode yang diterapkan pada penelitian ini.

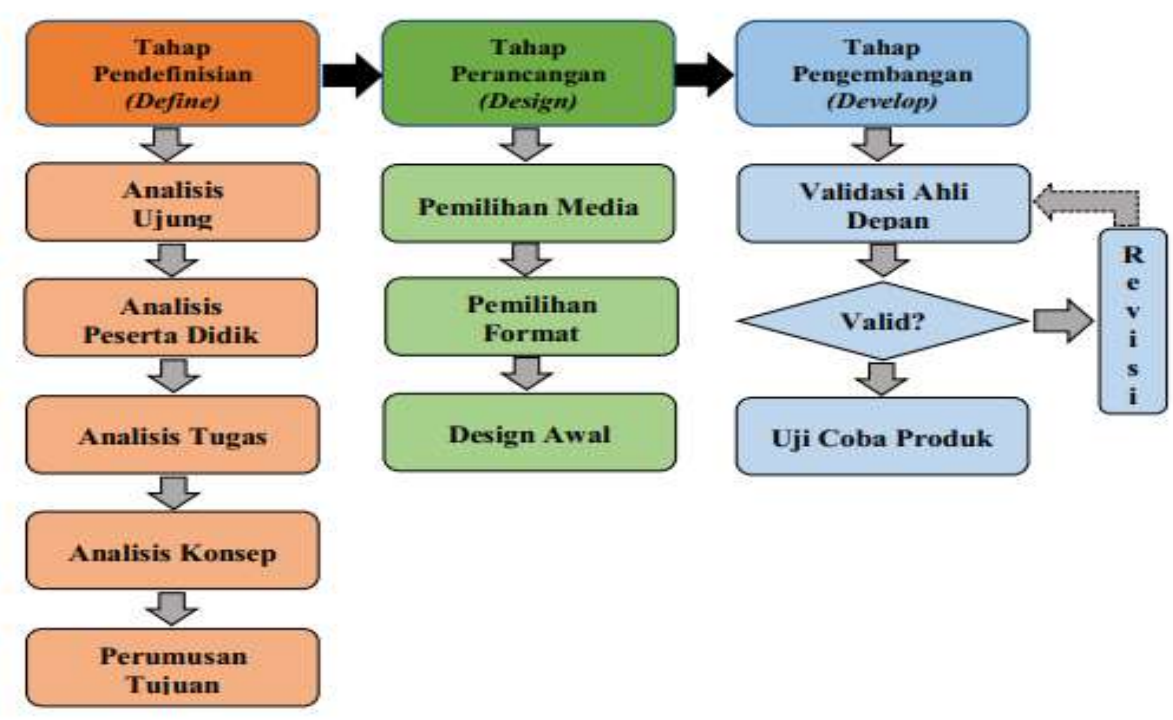

Gambar 1. Tahap-tahap pengembangan perangkat pembelajaran dalam penelitian

Instrumen yang digunakan pada penelitian ini berupa kuesioner ahli media dan kuesioner respon. Data yang diperoleh berupa mixed method (data kualitatif kemudian di ubah menjadi data kuantitatif). Analisis data menggunakan skala Likert dengan skala 1 (terendah) sampai dengan 5 (tertinggi).

\section{HASIL DAN PEMBAHASAN}

Berikut tahapan-tahapan modifikasi teori Thiagarajan, Semmel, and Semmel (Trianto, 2010) yang gunakan pada penelitian ini.

Tahap Pendefinisian: Tahap pendefinisian tahap pendefinisian bertujuan untuk menentukan dan mendefinisikan

syarat-syarat pembelajaran. Tahap ini meliputi analisis awalakhir, analisis peserta didik, analisis materi, analisis tugas, perumusan tujuan. Hasil analisis pada tahap ini sebagai berikut:

a. Analisis awal-akhir

Beberapa alat peraga yang digunakan sebagai prasaran kegiatan pembelajaran belum memadai serta penggunaan alat yang ada kurang maksimal. Hasil analisis tersebut menghasilkan beberapa masalah yang terjadi dalam pelaksanaan praktikum menggunakan alat peraga di sekolah. 
Berdasarkan masalah tersebut, maka peneliti merasa perlu mengembangkan alat peraga sederhana yaitu berupa bak simulasi gelombang, untuk memudahkan peserta didik dalam memahami materi gelombang dalam kegiatan pembelajaran fisika.

b. Analisis peserta didik

Analisis kebutuhan dalam penelitian ini berupa kegiatan untuk mengumpulkan informasi tentang kebutuhan berdasarkan kondisi faktual dan kondisi ideal suatu sekolah yang meliputi keberdayaan sekolah dalam melaksanakan kegiatan pembelajaran yang efektif khususnya untuk mata pelajaran fisika. Hasilnya menunjukkan bahwa peserta didik tertarik ketika pembelajaran dilakukan dengan percobaan langsung dan hasil observasi menunjukkan bahwa alat peraga yang digunakan untuk mendukung proses pembelajaran materi gelombang belum tersedia.

c. analisis tugas

Pada tahap analisis tugas, peneliti melihat hasil kuesioner pra penelitian untuk menganalisis kebutuhan peserta didik terhadap alat peraga yang akan dikembangkan. Kemudian analisis kebutuhan tersebut yang menjadi tujuan pembuatan alat peraga sederhana berupa bak simulasi gelombang

d. analisis materi

Materi-materi tersebut terdiri Faktor-faktor pembentuk gelombang, pembagian gelombang dan sifat-sifat gelombang, pada materi tersebut tidak ada peragaan bagaimana bentuk dan sifat-sifat gelombang karena belum adanya alat peraga bak simulasi gelombang di laboratorium. Kemudian peneliti mengumpulkan alat dan bahan untuk membuat alat peraga bak simulasi gelombang.

e. rumusan tujuan

Perumusan tujuan yang dihasilkan pada tahap ini yaitu menghasilkan produk alat peraga bak simulasi gelombang. Tujuan dari pembuatan alat peraga tersebut untuk mempermudah peserta didik dalam memahami konsep materi gelombang.

Tahap perancangan (design): Tahap design merupakan tahap pembuatan rancangan produk berupa alat peraga sederhana bak simulasi riak gelombang. Hasil yang diperoleh dalam langkah merancang alat peraga sebagai berikut:

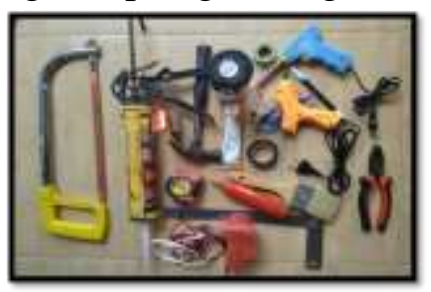

Gambar 2. Alat

Menyiapkan bahan dan alat-alat yang digunakan seperti Kaca, Paralon, Gergaji Besi, Solder, Ciller, Bor tangan, Lem Bakar, Selotip, Tang, Martil, Kabel, Spidol, Kabel, Meteran, Tinol, dsb.

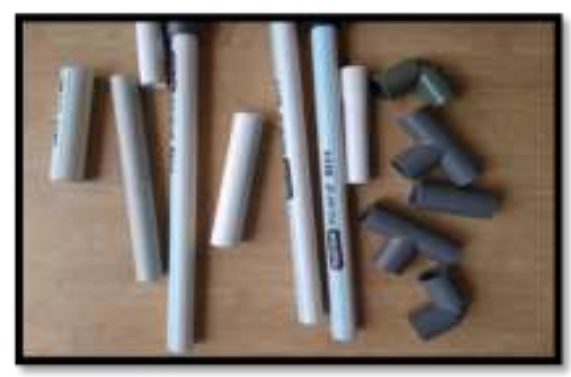

Gambar 3. Bahan

Selanjutnya potongan-potongan paralon tersebut di rangkai menjadi sebuah dudukan berbentuk empat pesergi panjang dengan ukuran $35 \times 50 \mathrm{~cm}$, rangka tersebut diberi kaki-kaki sebanyak 4 buah dengan tinggi $35 \mathrm{~cm}$, selain kaki pada rangka juga diberi dudukan atau tower/tiang untuk lampu/LED dan juga 
dudukan untuk menempatkan pegas dan pemantik gelombang (Gambar 4).

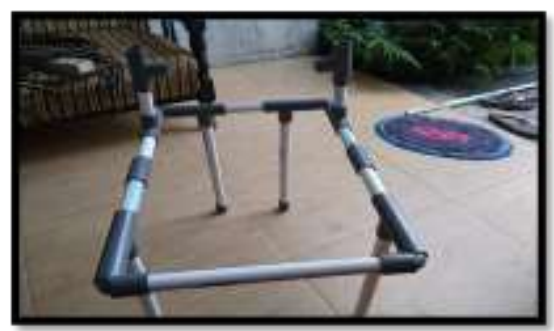

Gambar 4. Dudukan Bak Riak Gelombang

Dudukan bak kaca dalam penelitian ini dirancang secara portable sehingga mudah untuk digunakan dan juga dibongkar pasang ketika akan diperagakan. Rangka atau dudukan bak kaca berbentuk segi empat panjang menyesuaikan bentuk bak kaca, rangka dibuat dengan menggunakan potonganpotongan pipa paralon PVC berukuran 1/2 inchi yang dihubungkan atau disambungkan dengan shock lurus, shock $\mathrm{T}$ dan juga shock $\mathrm{L}$ dan Setelah rangka dirangkai dan mendapatkan ukuran dan bentuk yang sesuai selanjutnya rangka dicat dengan warna sesuai keinginan, agar menambah estetika dari alat peraga yang dibuat (Gambar 5).

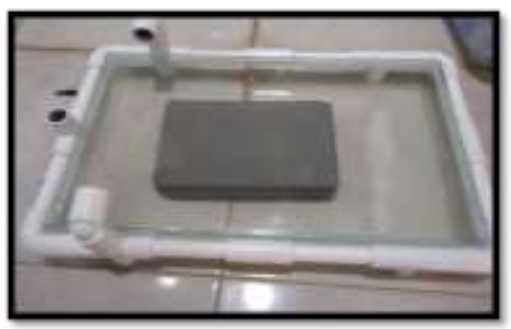

Gambar 5. Rangka Bak Riak Gelombang

Tujuan pembuatan bak penampungan air agar simulasi gelombang air akan ditampilkan pada bak penampungan air yang terbuat dari kaca trasparan setebal 5 mm. yang sudah dipotong sesuai ukuran yang telah ditentukan, lem kaca yang digunakan untuk merekatkan kaca satu sama lain sehingga membentuk bak (Gambar 6).

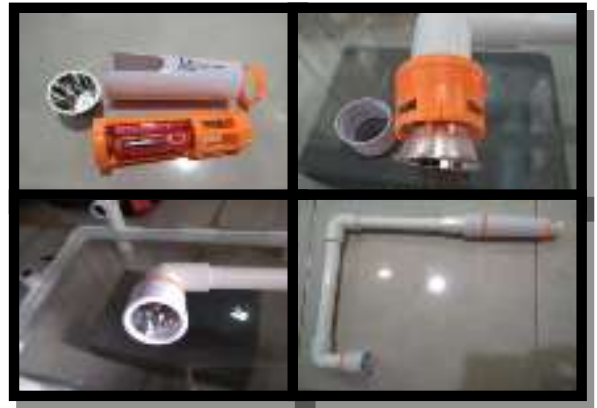

Gambar 6. Penampang Air

Proses selanjutnya adalah pembuatan lampu bak simulasi gelombang yang akan digunakan pada bak air untuk menghasilkan cahaya dan menerangi bak air untuk memperoleh hasil gelombang pada dasar atau pada lantai serta bagian atas pada bak air (Gambar 7).

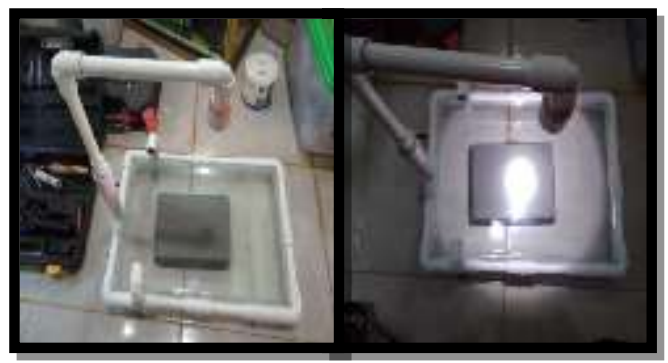

Gambar 7. Lampu Bak Simulasi Gelombang

Setelah senter yang telah dimodifikasi dirangkai dengan paralon maka jadilah tower LED sebagai pencahayaan yang nantinya akan diproyeksikan. Selanjutnya tower atau tiang di rangkai pada rangka bak kaca untuk menyesuaikan pencahayaan dan juga kualitas bayangan atau proyeksi yang dihasilkan (Gambar 8).

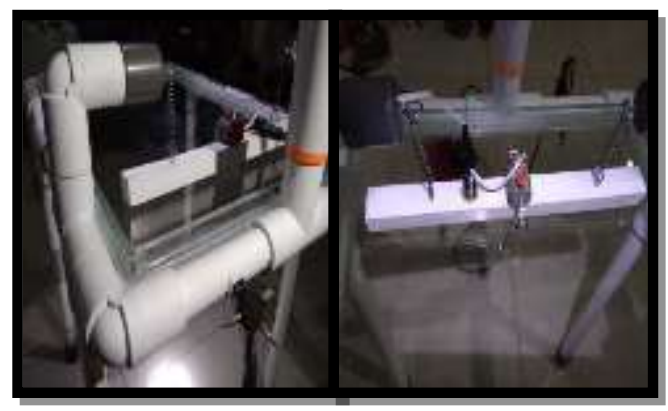

Gambar 8. Tower LED 
Pemantik gelombang yang digunakan dalam alat peraga ini menggunakan dynamo atau motor dari bekas mobilmobilan yang sudah tidak terpakai, dynamo kemudian diberi dudukan berupa potongan atau balokan kayu yang telah dilapisi cat agar tidak basah yang berguna sebagai pembias gelombang, dynamo diberi bandul pada salah satu kipasnya agar terjadi getaran konstan.

Pada bagian sisi ujung kanan dan kiri balokan kayu diberi pengait yang akan dikaitkan pada 2 buah pegas kecil, yang berguna sebagai penghasil getaran. pemakain atau penggunaan sumber tegangan dengan menggunakan adaptor atau batarai AA 1,5 V (Gambar 9).

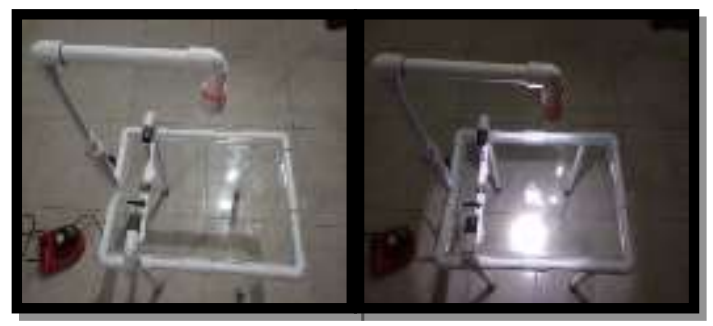

Gambar 9. Pemantik Gelombang
Setelah semua perangkat dan aksesoris alat peraga selesai di uji coba fungsinya, selanjutnya alat dirangkai secara keseluruhan untuk mendapatkan hasil akhir dari alat peraga bak simulasi gelombang.

Tahapan pengembangan (develop): pada tahap ini dilakukan beberapa validasi dan respon untuk mendapatkan alat peraga yang berkualitas. Beberapa validasi diantaranya validasi ahli media, validasi ahli materi dan respon guru dan peserta didik. Hasil validasi diperoleh dari validator yaitu dosen-dosen yang sesuai dengan kriteria yang telah ditentukan. Revisi dilakukan berdasarkan saran dari validator. Skor rata-rata total yang diberikan oleh para validator adalah 5 artinya produk alat peraga baik dan dapat digunakan dengan sedikit revisi sehingga perangkat pembelajaran fisika bak simulasi riak gelombang dapat di uji coba pada pembelajaran. Berikut rekapitulasi skor validasi (Tabel 1).

Tabel 1. Rekapitulasi Skor Validasi

\begin{tabular}{cccccc}
\hline $\begin{array}{c}\text { Pengembangan } \\
\text { Produk }\end{array}$ & $\begin{array}{c}\text { Validasi } \\
\text { Materi }\end{array}$ & $\begin{array}{c}\text { Validasi } \\
\text { Media }\end{array}$ & $\begin{array}{c}\text { Rerata } \\
\text { Skor } \\
\text { Perolehan }\end{array}$ & Kriteria & Kesimpulan \\
\hline $\begin{array}{c}\text { Alat peraga bak } \\
\text { simulasi riak } \\
\text { gelombang }\end{array}$ & $88,30 \%$ & $77,95 \%$ & $83,1 \%$ & $\begin{array}{c}\text { Sangat } \\
\text { Akurat }\end{array}$ & $\begin{array}{c}\text { Memenuhi kriteria sangat } \\
\text { akurat sehingga dapat } \\
\text { digunakan untuk uji coba }\end{array}$ \\
\hline
\end{tabular}
produk.

Berdasarkan Tabel 1 dapat diketahui bahwa persentase rata-rata keakuratan produk yang dikembangkan adalah $83,1 \%$. Skor keakuratan tersebut dalam katagori sangat akurat. Artinya, produk dapat digunakan tanpa perlu revisi lagi. Akan tetapi revisi dilakukan berdasarkan saran dari validator ahli materi dan ahli media untuk penyempurnaan produk.

Tabel 2. Saran Ahli Materi Dan Ahli Media

\begin{tabular}{llll}
\hline \multicolumn{2}{c}{ Ahli Materi } & \multicolumn{1}{c}{ Perbaikan } & \multicolumn{2}{c}{ Ahli Media } & \multicolumn{1}{c}{ Perbaikan } \\
\hline - Lengkapi buku & - Sudah di buat sesuai & - Saklar di fungsikan & Sudah diperbaiki \\
panduan praktikum & saran & dan perbaiki yang & $\begin{array}{l}\text { Sesuai dengan } \\
\text { sesosedur dan }\end{array}$ \\
sesuai dengan ciri- & rusak & saran-saran \\
ciri gelombang yang & & & \\
bisa di jelaskan & & & \\
melalui alat tersebut & & & \\
\hline
\end{tabular}




\begin{tabular}{|c|c|c|c|}
\hline Ahli Materi & Perbaikan & Ahli Media & Perbaikan \\
\hline $\begin{array}{lr}\text { - } & \text { Tambahankan } \\
\text { sifat untuk } & \text { gelombang } \\
\text { refleksi } & \text { untuk } \\
\text { interperensi } & \end{array}$ & $\begin{array}{lr}\text { - Pada } & \text { sifat } \\
\text { gelombang sudah di } \\
\text { tambahakan sesuai } \\
\text { saran }\end{array}$ & $\begin{array}{l}\text { - Kesesuaian alat peraga } \\
\text { dengan konsep yang di } \\
\text { sajiakan dan kejelasan } \\
\text { petunjuk }\end{array}$ & 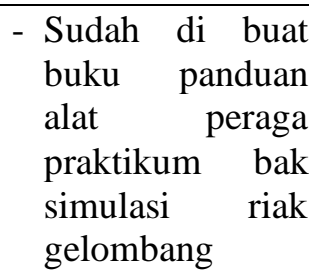 \\
\hline $\begin{array}{lr}\text { - Pada panduan di buat } \\
\text { sub judul yang jelas } \\
\text { untuk r masing- } \\
\text { masing r sifat } \\
\text { gelombang }\end{array}$ & $\begin{array}{lr}\text { - Terdapat beberapa } & \text { sifat gelombang } \\
\text { yang di perbaiki dan } \\
\text { penjelasan } & \text { masing- } \\
\text { masing } & \text { sifat } \\
\text { gelombang } & \text { pada } \\
\text { buku } & \text { panduan } \\
\text { praktikum } & \end{array}$ & $\begin{array}{lr}\text { - Saklar di fungsikan } \\
\text { dan panduan manual } \\
\text { book/buku panduan } \\
\text { praktikum atau } \\
\text { petunjuk alat peraga }\end{array}$ & $\begin{array}{l}\text { - Saklar sudah di } \\
\text { fungsikan,dan } \\
\text { sudah di buat } \\
\text { buku panduan } \\
\text { alat peraga }\end{array}$ \\
\hline
\end{tabular}

Data yang terkumpul dari hasil uji coba ini terdiri dari: (1) data hasil uji coba keakuratan ahli media dan ahli materi pembelajaran (2) data hasil uji coba pada pendidik (kemenarikan) dan peserta didik (penggunaan). Data hasil uji coba keakuratan ahli materi dan media hasil yang diperoleh sangat akurat. Dengan demikian dapat disimpulkan bahwa bahan ajar berupa alat peraga bak riak gelombang telah akurat dari segi media dan materi. Keakuratan alat peraga dapat mempermudah dalam memahami konsep yang dipelajari (Muzaky \& Handhika, 2015; Sobri \& Khaeroni, 2016).

Selanjutnya berdasarkan respon pendidik hasil yang diperoleh sangat menarik. Dengan demikian dapat disimpulkan bahwa bahan ajar alat peraga bak riak gelombang telah menarik dan layak untuk uji coba kepeserta didik. Kemenarikan alat peraga yang dikembangkan dapat memotivasi peserta didik dalam proses pembelajaran (Widayanti, Yuberti, Irwandani, \& Hamid, 2018). Tabel 3 rekapitulasi hasil kemenarikan produk.

Tabel 3. Rekapitulasi Skor Kemenarikan Produk

\begin{tabular}{cccc}
\hline Aspek Penilaian & Penilaian Pendidik & Kriteria & Kesimpulan \\
\hline Kualitas Isi & $87,62 \%$ & Sangat Menarik & \\
$\begin{array}{c}\text { Tampilan media } \\
\text { Kemudahan } \\
\text { Penggunaan }\end{array}$ & $93,33 \%$ & Sangat Menarik & $\begin{array}{c}\text { Memenuhi kriteria sangat } \\
\text { menarik sehingga produk } \\
\text { layak digunakan }\end{array}$ \\
\hline
\end{tabular}

Pada uji coba penggunaan dilakukan dua kali, uji coba kelompok kecil dan uji coba kelompok besar. Uji coba kelompok kecil diambil dari beberapa peserta didik sedangkan pada uji coba lapangan dilakukan ditiga sekolah, kemudian peserta didik memberikan skor dengan cara mengisi kuesioner yang diberikan. Kuesioner berisi pertanyaan meliputi aspek kualitas isi, materi, kemudahan penggunaan, hasil yang diperoleh data uji coba kelompok kecil dan uji coba lapangan (Tabel 4). 
Tabel 4. Rekapitulasi Skor Penggunaan Produk Peserta Didik

\begin{tabular}{|c|c|c|c|c|c|}
\hline $\begin{array}{c}\text { Aspek } \\
\text { Penilaian }\end{array}$ & $\begin{array}{c}\text { Uji Kelompok } \\
\text { Kecil }\end{array}$ & $\begin{array}{c}\text { Uji } \\
\text { Lapangan }\end{array}$ & $\begin{array}{c}\text { Rerata Skor } \\
\text { Perolehan }\end{array}$ & Kriteria & Kesimpulan \\
\hline Kualitas Isi & $92,13 \%$ & $89,33 \%$ & $90,73 \%$ & Sangat & Memenuhi \\
\hline Materi & $90,67 \%$ & $88,93 \%$ & $89,8 \%$ & $\begin{array}{c}\text { Menarik } \\
\text { Sangat } \\
\text { Menarik }\end{array}$ & $\begin{array}{l}\text { kriteria sangat } \\
\text { menarik sehinga } \\
\text { produk layak }\end{array}$ \\
\hline $\begin{array}{l}\text { Kemudahan } \\
\text { Penggunaan }\end{array}$ & $91,17 \%$ & $88,99 \%$ & $90,08 \%$ & $\begin{array}{c}\text { Sangat } \\
\text { Menarik }\end{array}$ & $\begin{array}{l}\text { diuji coba lebih } \\
\text { luas }\end{array}$ \\
\hline
\end{tabular}

Dari hasil analisis ujicoba telah bisa menggambarkan bahwa alat peraga bak riak gelombang yang dibuat ini sudah sesuai dengan kriteria yang diinginkan peserta didik di lapangan.

Penelitian pengembangan ini telah menghasilkan suatu alat peraga pembelajaran, alat peraga hasil pengembangan disusun secara sistematis dan konsisten. Pengembangan produk ini dilengkapi buku panduan atau petunjuk pembuatan alat peraga bak riak gelombang untuk memudahkan para peserta didik untuk membuat alat peraga dan memudahkan peserta didik dalam memahami materi gelombang (Widayanti et al., 2018).

Alat peraga bak simulasi gelombang salah satu media pembelajaran yang dapat digunakan pendidik tidak hanya sekedar belajar tetapi bisa sambil bermain dalam melaksanakan kegiatan pembelajaran dan peserta didik dapat lebih mudah memahami konsep pembelajaran dengan baik.

\section{KESIMPULAN DAN SARAN}

Penelitian ini telah menghasilkan produk berupa alat peraga bak riak gelombang. Skor yang diperoleh dari ahli materi dan ahli media dengan kategori "Sangat Akurat", skor dari guru dengan kategori "Sangat Menarik" dan Respon uji coba peserta didik yang dilakukan pada kelompok kecil dan uji coba lapangan mendapatkan kategori "Sangat Menarik". Hal ini menunjukkan bahwa media pembelajaran yang dikembangkan dapat diterima sebagai media yang dapat digunakan dalam pembelajaran guna mempermudah memahami materi gelombang.

Pada penelitian selanjutnya agar dapat mengembangkan alat peraga bak simulasi gelombang yang lebih menarik dan terintegrasi dengan nilai-nilai keislaman.

\section{DAFTAR PUSTAKA}

Desy, Desnita, \& Raihanati. (2015). Pengembangan Alat Peraga Fisika Materi Gerak Melingkar untuk SMA. Prosiding Seminar Nasional Fisika (E-Journal) SNF2015, IV , 39-44.

Huriawati, F., Purwandari, \& Permatasari, I. (2015). Pengembangan Buku Komik Fisika Pokok Bahasan Newton Berbasis Konstruktivisme untuk Meningkatkan Motivasi Belajar Siswa. Jurnal Pendidikan Fisika Dan Keilmuan, 1.

Irsyadsyah, M., \& Prabowo. (2015). Pengembangan Alat Peraga Resultan Gaya Sebagai Media Pembelajaran Fisika Materi Pokok Kesetimbangan Partikel. Jurnal Inovasi Pendidikan Fisika, 4(2), 45-49.

Kasih, F. R. (2017). Pengembangan Film Animasi dalam Pembelajaran Fisika pada Materi Kesetimbangan Benda Tegar di SMA. Tadris: Jurnal Keguruan Dan Ilmu Tarbiyah, 2(1), 41.

Lubis, I. R., \& Ikhsan, J. (2015). Pengembangan Media Pembelajaran Kimia Berbasis Android Untuk Meningkatkan Motivasi Belajar Dan 
Prestasi Kognitif Peserta Didik Sma. Jurnal Inovasi Pendidikan IPA, 1(2), 191.

Maharani, M., Wati, M., \& Hartini, S. (2017). Pengembangan Alat Peraga pada Materi Usaha dan Energi untuk Melatihkan Keterampilan Proses Sains melalui Model Inquiry Discovery Learning (IDL) Terbimbing. Berkala Ilmiah Pendidikan Fisika, 5(3), 351-367.

Muslem, A. (2017). The Effectiviness Of Immersive Multimedia Learning With Peer Support On English Speaking and Reading Aloud. International Journal of Instruction, 10(1).

Muzaky, A. F., \& Handhika, J. (2015). Penggunaan Alat Peraga Sederhana Berbasis Teknologi Daur Ulang untuk Meningkatkan Pemahaman Konsep Materi Vektor dalam Kelas Remedial SMKN 1 Wonoasri Tahun Pelajaran 2014/2015. In Prosiding Seminar Nasional Fisika dan Pendidikan Fisika (SNFPF) (pp. 129-134).

Nomleni, F. T., \& Manu, T. S. N. (2018). Pengembangan Media Audio Visual dan Alat Peraga dalam Meningkatkan Pemahaman Konsep dan Pemecahan Masalah. Scholaria: Jurnal Pendidikan Dan Kebudayaan, 8(3), 219-230.

Prihatiningtyas, S., Prastowo, T., \& Jatmiko, B. (2012). Pengembangan Perangkat Pembelajaran perangkat pembelajaran Fisika SMP Berbasis Simulasi Virtual dan Kit Sederhana dengan Model Pembelajaran Langsung dan Kooperatif untuk Mengajarkan Keterampilan Psikomotor dan Afektif pada Pokok Bahasan Alat Optik. JPPS: Jurnal Peneilitian Pendidikan Sains, 2(1), 135-141.

Prihatiningtyas, S., \& Putra, I. A. (2018). Efektivitas Penggunaan Alat Peraga Sederhana Berbasis Pendekatan
Sains Teknologi Masyarakat pada Materi Fluida Statis. JRKPF UAD, 5(9), 102-107.

racy religia, hainur rasyid achmadi.

(2017). Pengembangan KIT

Sederhana Stirling Engine pada Materi Termodinamika sebagai Media Pembelajaran Fisika SMA. Inovasi Pendidikan Fisika, 6(3), 113-119.

Rahman, A. Z., Hidayat, T. N., \& Yanuttama, I. (2017). Media Pembelajaran Ipa Kelas 3 Sekolah Dasar Menggunakan Teknologi Augmented Reality Berbasis Android. Seminar Nasional Teknologi Informasi Dan Multimedia, 4-6-43.

Saepuzaman, D., \& Yustiandi. (2017). Pengembangan Alat Peraga dan Lembar Kerja Percobaan Penentuan Koefisien Restitusi untuk Meningkatkan Kemampuan Siswa Bereksperimen. JPPPF - Jurnal Penelitian \& Pengembangan Pendidikan Fisika, 3(2), 145-150. https://doi.org/10.21009/1.03204

Saregar, A. (2016). Pembelajaran Pengantar Fisika Kuantum dengan Memanfaatkan Media PhET Simulation dan LKM Melalui Pendekatan Saintifik: Dampak pada Minat dan Penguasaan Konsep Mahasiswa. Jurnal Ilmiah Pendidikan Fisika Al-Biruni, 5(1), 53-60.

https://doi.org/10.24042/jpifalbiruni. v5i1.105

Sobri, \& Khaeroni. (2016). Penggunaan Alat Peraga Untuk Meningkatkan Pemahaman Konsep Dasar Matematika. Primary, 8(2), 185204.

Sohibun, \& Ade, F. Y. (2017). Pengembangan Media Pembelajaran Berbasis Virtual Class Berbantuan Google Drive. Pengembangan Media Pembelajaran Berbasis Virtual Class Berbantuan Google Drive, 2(2), 
121-129.

Subekti, \& et al. (2018). Mengembangkan Literasi Informasi Melalui Belajar Berbasis Kehidupan Terintegrasi STEAM untuk Menyiapkan Calon Guru Sains dalam Menghadapi Era Revolusi Industri 4.0: Revieu Literatul. Education and Human Development Journal, 3(1), 81-90.

Suprihatiningsih, \& Wiyarno, Y. (2015). Pengembangan Bahan Ajar Berbasis Komputer pada Mata Pelajaran Pendidikan Kewarganegaraan untuk Siswa Sekolah Menengah Atas. Jurnal Teknologi Pembelajaran Devosi, 5(1).

Trianto. (2010). Pengantar Penelitian Pendidikan bagi Pengembangan Profesi Pendidikan \& Tenaga Kependidikan. Jakarta: Kencana.

Ulmi, F., Murtiani, \& Hidayati. (2013). Pengembangan Bahan Ajar Fisika Mengintegrasikan Nilai Nilai Karakter Al Qur'an Pada Materi Fluida Statis dan Fluida Dinamis untuk Pembelajaran Siswa Kelas XI SMA. Pillar of Physics Education, 2(1), 105-112.

Widayanti, \& Yuberti. (2018). Pengembangan Alat Praktikum Sederhana Sebagai Media Praktikum Mahasiswa. JIPFRI (Jurnal Inovasi Pendidikan Fisika Dan Riset Ilmiah), 2(1), 21-27. https://doi.org/10.30599/jipfri.v2i1.1 61

Widayanti, Yuberti, Irwandani, \& Hamid, A. (2018). Pengembangan Lembar Kerja Praktikum Percobaan Melde Berbasis Project Based Learning. Jurnal Pendidikan Sains Indonesia, 6(1), 24-31. https://doi.org/10.24815/jpsi.v6i1.10 908 